\title{
Introduction: theorizing the G20
}

\section{Steven Slaughter}

This volume provides a range of perspectives on the significance and operation of the G20 (Group of Twenty). The G20 was convened in 2008 as a summit of world leaders from economically significant states in response to the 2008 global financial crisis and followed on from the preceding G8 (Group of Eight). The G20 is an informal grouping which has a delimited membership of economically significant states, which focuses on policy issues relating to global economics and finance. From its inception, the G20 has been beset by questions about its legitimacy and authority given that it is a self-selected forum of wealthy states that excludes less developed states and sits outside the existing forms of multilateral global governance. The influence of the G20 has also been unclear. While it helped coordinate a significant immediate response to the 2008 global financial crisis, its influence has waned as the effects of the immediate crisis have lessened, and poor global economic growth has become the 'new mediocre' which governments are attempting to grapple with (Luckhurst 2016: 161). As such, the yearly summits have varied in respect to developing noteworthy outcomes or effective policy deliberations. Nevertheless, despite this varying influence and profile, the G20 provides a rare opportunity for world leaders and policy makers to meet, discuss and coordinate responses to global issues that have not been resolved in other forums or International Organizations (IOs)/ Intergovernmental Organizations. It thus performs a potentially important role in global governance.

In light of these issues and concerns, the future of the G20 is uncertain and requires further analysis. This volume considers the current and future significance of the G20 by engaging various accounts of International Relations (IR) theory to examine the political impact of this particular form of global governance. Rather than focusing upon the narrow accounts of the G20 derived from international policy observers or the discipline of economics, IR theory represents a broader range of political positions, which analyze the various factors that influence world politics. As such, IR theory is a body of thought which examines how the 
G20 influences world politics, as well as examines what direction the G20 could or should take in the future. IR theory also considers broader questions of power, a wider range of political problems and limits as well as interrogating the ethical issues involved. This volume lays out a range of different positions drawn from IR theory and applies them to the ongoing operation of the G20. In doing so, this volume considers three general questions. First, how do particular theories of IR understand the political influence and significance of G20 summitry? Second, what political dynamics and policy issues of the G20 do particular theories of IR focus upon? Third, what prospects do particular theories of IR place on the possibility that the G20 could be developed or reformed to be more effective? Individual chapters in this volume will each explore a particular theory. In order to articulate a wide range of theoretical considerations about the political role of the G20, this introduction sets out what IR theory is, what the main elements of the declared purpose and operation of the G20 are, and broadly articulates why considering IR theory is important to the future of the G20.

\section{INTERNATIONAL RELATIONS THEORY}

The discipline of IR was formed in the aftermath of the First World War and is therefore a relatively recent discipline of thought. While it was originally focused on avoiding interstate war, it has progressed to address a wide range of pressing issues in world politics, including civil conflict and the global implications of human rights, economics and environmental issues. The original goal of preventing war and the emerging purpose of addressing other global problems, suggests that IR is an approach that aspires to consider and guide practical action in respect to world politics. IR theory is therefore best seen as a 'practical discourse' involving specific types of systematic assumptions about how the world works (Reus-Smit and Snidal 2010: 7). That is to say that IR theory attempts to make the assumptions that people have about the world explicit, rather than being a 'prisoner of unstated assumptions' (Keohane 1996: 4). Consequently, IR theory is a body of thought that attempts to understand and explain the underlying dynamics and drivers of world politics. There are a variety of strategic, political, economic, cultural and ethical considerations which shape the various issues facing leaders and officials in world politics. As such, academics and observers of world politics have attempted to systematically think about the international realm in order to understand which of the drivers and forces at work are 
most important in explaining why things happen as they do and critically evaluate what is most important in achieving desired political outcomes.

Consequently, the various theories of IR are specific sets of assumptions about what is important in world politics. These assumptions have developed into intellectual traditions which act as specific perspectives and frameworks that analyze particular political drivers and dynamics, establish the appropriate methods of analysis and set out the purpose of study and/or political action. As such, theories can be ideas that inform a perspective with respect to empirical academic analysis, as well as ideas that inform a program of political action. As Christian Reus-Smit and Duncan Snidal (2010: 7) indicate:

Different perspectives emphasize different issues that demand action, and arrive at different conclusions about types of action required. But whether they are concerned with the promotion of peace, order, institutional development, economic well-being, social empowerment, or ending global forms of discrimination, or whether they recommend the balancing of power, the promotion of free trade, the intensification of social contradictions, or resistance to all institutions and discourses of social power, they are nonetheless animated by the practical question of how we should act.

The question of how we should act involves developing accurate and useful empirical understandings of the world, as well as considering the political implications of specific forms of practical action. Consequently, it is important to emphasize that IR theory's intent to make assumptions explicit involves consideration of both the empirical and normative implications of world politics.

From the outset it is critical to emphasize the diversity of intellectual positions regarding the assumptions that are made within the field of IR. Particular traditions of IR theory possess perspectives which focus on specific dynamics and purposes drawn from assumptions about what is politically important. For example, realism is a theory of IR which generally contends that it is the power of states that is the most important driver of world politics. For realists, it is the power of states that influences the realization of national security, which is the most important goal of any nation-state from this realist perspective. This tradition explores the strategic challenges and tensions that stem from these security drivers and purposes. But different theories make different practical assumptions about what drivers and what outcomes are important, often differing in their interpretations. In doing so, they engage and utilize different understandings of key political concepts such as security, power, prosperity, legitimacy and justice. Furthermore, these different understandings are directed by different purposes for different people and 
interests. The practical purpose of IR theory is to enable specific practical political responses for a variety of purposes and causes, rather than to solely consider political purposes that are currently realistic, feasible or 'policy relevant'.

Theory in this context refers to reflection on various sets of systematic assumptions about world politics. These assumptions have been heavily influenced by the changing nature of world politics and the impact of international crises and problems on policy makers. Indeed, the original focus of IR in the 1930s until the 1960s was firmly on security and strategic issues facing Western policy makers in the form of the Second World War and the Cold War. In the 1970s, the rising impact of economic interdependence led to the formation of the IR subfield of International Political Economy (IPE), which focused on the role of transnational businesses and the role of IOs set up by states. In the 1980s, there was increased concern in IR scholarship on the impact of human rights, decolonialization, women's rights and environmental issues - which reflected the emerging struggles of social movements with respect to these issues. Since the 1990s, processes of interdependence and globalization have led IR theory to depart from its traditional focus on the relations and politics between states and more actively consider the rise of global and transnational relations that cut across domestic and international politics. IR theory in this period focused more on the political impact of transnational businesses, transnational civil society and global governance. IR theory is a body of scholarship that has a wide range of different assumptions about a growing array of drivers that influence how global conflict and cooperation occurs.

IR theory has also been influenced by changes in political culture, social science and political philosophy. Indeed, the changing focus of IR theory reflects a broadening ontology which includes a wider range of real-world dynamics as noted above. Early IR theory reflected a political culture which largely reflected the interests of Western states, especially the USA. Such approaches of IR theory such as realism argue that states need to adapt to the realities of world politics to realize their national interests and promote security in world politics. By contrast, liberal accounts argue that we need to ensure that international cooperation is maintained to ensure the collective security of states and that global capitalism works smoothly. Since the 1970s, the broadening ontology of IR theory was also driven by the increasing influence of Marxist, Frankfurt School critical theory, post structuralism, post colonialism and feminism in the field of IR, which led to the rise of critical approaches in IR theory. In different ways, these approaches consider a range of political drivers that go beyond the realist and liberal focus on the state 
and questions of security and wealth, to consider wider questions of exploitation, inequality, injustice and social change. These critical approaches sought to challenge the influential assumptions of realist and liberal theory (Smith 2004), as well as identify and create opportunities for radical change in world politics in order to develop and promote various visions of human emancipation. In this context, the rising presence and influence of these critical theories is entwined with the changing nature of the substance of world politics.

In addition to the changing nature of world politics and social science there is also the question about the purpose and goal of political action and reflection in the form of IR theory. Some theories have advanced positivist notions of testing a theory's ability to explain and predict events in world politics. This includes the significant impact of rational choice theory on the development of IR theory to explain the activity of states (see Waltz 1979). The field of IR has also seen the development of theories such as the English School and constructivism which seek to interpret the norms and beliefs which are prominent in world politics. It is also important to see that the development of various critical theories have opened up reflections of world politics to put more emphasis on the questions of normative purpose and judgement in world politics. While in the 1960s, the IR scholar Martin Wight (1966: 33) claimed that IR theory was 'the theory of survival', not the good life, it is now the case that such a claim would be controversial because of increasing public awareness of ethical issues in world politics and more systematic action by global governance bodies. This reflects the actions of states, IOs and nongovernmental organizations (NGOs) which participate in global discussions as having ineradicable moral dimensions. As such, IR theory stands at the interface between 'utopia and reality' in studying and contributing to political debates (Reus-Smit and Snidal 2010: 3. See Carr 2016 [1941]). In this context, the growing presence of global governance has moved world politics beyond pure survival and IR theory is one form of thought that participates in considering the practical interplay of morality and power.

The relationship between utopia and reality is also confronted by the increasingly complicated nature of global governance. Global governance refers to the various ways that states and other actors establish rules and processes of cooperation. The often-cited definition of governance by the Commission on Global Governance (1995: 4) claims that:

governance is the sum of the many ways individuals and institutions, public and private, manage their common affairs. It is a continuing process through which conflicting or diverse interests may be accommodated and co-operative 
action may be taken. It includes formal institutions and regimes empowered to enforce compliance, as well as informal arrangements that people and institutions either have agreed to or perceive to be in their interest.

While non-state actors can make informal rules, it is states that are the primary curators of formal and informal forms of global governance. Formal forms of global governance are evident in multilateral IOs and international law with respect to specific issues which are created by formal treaties. Informal global governance refers to forums or summits created by 'an explicitly shared expectation-rather than a formalized agreement' by a specific group of states without any established agency or legal agreement (Vabulas and Snidal 2013: 197). While global cooperation has long been evident in the various practices of international law and diplomacy, in recent decades such forms of cooperation and governance have become extremely variegated, complicated and contested.

Indeed, various accounts of IR and IPE theory have helped unpack global governance and reveal the presence of global policy making in three distinct respects. First, IR theory has helped identify the bearing of multiple global and transnational problems which have provided incentives and the need for global governance to be further developed in either formal or informal arrangements. The rise of climate change diplomacy, global health governance, food security, and anti-corruption efforts all demonstrate that policy makers have responded unevenly and incompletely to these emerging global problems - which requires ongoing study. Second, IR theory has demonstrated the existence of various types of power and authority in world politics that extend beyond the hard power of powerful states in world politics to encompass the power of non-state actors and the power of ideas and discourse (Barnett and Duvall 2005; Avant et al 2010). Third, IR theory has played a role in revealing the various types of global governance and newly emerging types of formal and informal global governance, including the rising influence of transnational forms of governance established by civil society and business actors (Hale and Held 2011). Indeed, it is important to see that the G20 itself is a novel form of global governance that differs in important respects from formal multilateral IOs like the United Nations (UN), and while possibly having some historical antecedents in the form of the Concert of Europe of the 19th century (Mitzen 2013), came into operation due to specific reasons. Indeed, important to the rise of the G20 were the failures of established forms of global governance from the perspective of powerful states, especially with respect to operation of the Bretton Woods system (Wade 2011) and the impact of the 2008 global financial crisis (Drezner 2014). 
As a result, IR theory's ongoing engagement with global governance needs to include the G20 in all its complexity. Thinking about something as complicated as the role of the G20 in contemporary global politics requires making assumptions about what political dynamics are significant within the operation of this form of governance. These assumptions are often nested in particular traditions of IR theory. Consequently, these assumptions provide different accounts about how the G20 influences world politics, what issues the G20 should consider and how the G20 could be more effective in future.

\section{THE G20}

In order to explain IR theory's existing and possible engagement with the $\mathrm{G} 20$, it is important to consider the evolving purpose of the G20. The G20 leaders' forum is an informal summit for economic diplomacy and policy coordination, which involves executive leaders of the member states. The G20 was developed in response to the 2008 global financial crisis and has acted as a key site for political deliberation and policy coordination amongst the leaders from 19 member states, the President of the European Union (EU), the heads of a range of IOs and some states invited periodically by the country hosting the summit. The central purpose of the G20 is to facilitate international and intergovernmental cooperation and policy coordination amongst economically significant states in order to respond to economic crises and stabilize the global economy. This arrangement follows on from previous groupings of the 'G system' in the form of Group of Seven (G7) summits since 1975 and G20 finance ministers and central bank governors' meetings (G20 FM/CBG) since 1999. The formation of the G20 leaders' forum in 2008 resulted from the belief that rapid and effective intergovernmental coordination required a newly developed informal body that elevated discussions from finance ministers to executive leaders outside of the existing multilateral IOs (Kharas and Lombardi 2012; Cooper and Thakur 2013; Kirton 2013). The formation of the G20 also recognizes changes in the geopolitical context of world politics that requires a broader membership than the G8, as well as being aware that global economic decisions must include the active participation of emerging global economic powers such as China and India. The G20 summits enable various informal forms of dialogue between world leaders to produce mutually agreed policy priorities, which are expressed in a communiqué and are subsequently meant to be enacted by formal IOs 
and member governments. As such, the G20 has the capacity to act as an 'orchestrator' in global governance (see Abbott et al 2015).

The informality of the G20 is crucial to its purpose and operation. This development has been referred to as the 'rise of the informals' whereby the formal activity of diplomacy and IOs is being joined and supplemented by the informal summitry of world leaders and other government officials (Alexandroff and Brean 2015: 9. See also Vabulas and Snidal 2013). This informality is evident in that the G20, and preceding forums of the $\mathrm{G}$ system, are established and operate outside the multilateral protocols of the UN's system. The G20 has no constitution or treaty, no continuing secretariat or budget and, therefore, no capability to act independently from member states. Its informality is also evident in that its outputs are largely discursive and about communicating the positions and concerns of states in the hope of developing shared understandings rather than binding commitments or developing international law. The informality of the G20 is also evident in that its process and agenda is primarily determined each year by a separate host state. The host country plays an important function in setting the agenda of a G20 summit and thereby establishes the policy issues to be discussed and prioritized. While there have been debates about whether the G20 needs a permanent secretariat to process the information related to the issues it confronts (Cooper 2012: 17), these proposals have not been widely supported and therefore not enacted. However, there has been a long-standing arrangement (since the formation of the G20 FM/CBG) to create a 'Troika' of the host country plus the previous host and upcoming host to develop the G20's agenda and to enable some consistency of the policy agenda across different hosts.

While G7/8 and G20 meetings have been defined by the flexible and informal manner in which leaders can meet, a growing number of forms of activity and institutionalization are supporting these summits. Indeed, the summits have become a 'process' in the sense that there is significant activity occurring before the summit itself occurs. From the earliest days of the $\mathrm{G}$ system there has been the work of senior diplomats, referred to as 'Sherpas', who meet before the summit of world leaders to prepare the agenda. However, especially since the formation of the G20 FM/CBG forum in 1999, there has been an increasing array of officials and experts involved in planning the arrangements for the meetings of finance ministers (Kharas and Lombardi 2012: 3). This includes representatives from key IOs (Baker 2009: 203) and an intensification of the relationships that already existed between the G20 and a broad array of IOs and policy making networks (Eccleston et al 2013: 2). These policy networks 
involve the development of G20 working groups which include transgovernmental groups of government officials and outside experts within a specific policy area who are charged with preparing material for G20 deliberations (such as the Development Working Group). Furthermore, broader policy networks are evident in G20 efforts to engage social sectors in the form of outreach processes, which included the formal development of G20 outreach groups in 2013 in the form of the Think 20 (think tanks), Labour 20, Business 20, Civil 20, Youth 20 and (in 2015) the Women 20 (Slaughter 2015; Koch 2016). These transnational networks of experts and advocates recommend ideas and proposals for G20 leaders to consider and also scrutinize and publicize the G20's policy activity.

Therefore, it is the case that the G20 is now far more than just a free-form meeting of world leaders. The G20 has been increasingly referred to as a 'hub' for the governments of member states and global governance networks (Kirton 2013). This hub is nested in various networks whereby the G20 is 'the hub of other global groups that radiate to bring insights and influence into and out of the hub' (Kirton 2013: 35). Consequently, the G20 is a specific form of global governance referred to as a form of 'global summitry' which encompasses:

the architecture, institutions and, most critically, the political and policy behavior of the actors engaged in the influence of outcomes of common concern in the international system. Global summitry includes all actors international organizations, trans-governmental networks, states and non-state entities whether individuals, corporations or associations - that influence the agenda, the organization and the execution of global politics and policy (Alexandroff and Brean 2015: 2).

Importantly, this activity occurs in specific meetings of leaders and officials. While there is no doubt that efforts are continuing to be made to ensure that informal meetings of world leaders remain central to the G20, it is the case that these meetings are underpinned by increasingly institutionalized forms of multilevel and pluralistic policy making and diplomatic activity (Feinberg 2013). Akin to an 'iceberg', there are three levels of activity evident in the G20 (Alexandroff and Brean 2015: 9-10). First, there is the international level of leaders of states and diplomats. Second, there is a governmental and transgovernmental level of policy making officials and networks in the form of the various working groups and meetings of ministers. Third, there are transnational and subnational networks of experts and advocates, especially in the form of the G20 outreach groups. There is now a significant level of policy making activity occurring amongst an array of diplomats, regulators, experts and 
advocates from both within and beyond member governments during the planning and lead up to G20 summits. Importantly for the purposes of this volume, there are differing perspectives and accounts as to how significant the various levels of the G20 summitry are for the political influence of this form of global governance.

These various levels of the G20's summitry indicate that the G20 has rapidly emerged to be a complex form of global governance - not merely an ad hoc meeting of world leaders. This complexity also has consequences for the controversies and challenges facing the practical operation of the G20. There are several key political controversies and challenges facing the G20. First, the membership of the G20 is controversial because it was drawn up by members of the G7 and the selection process of the membership was not developed with clear criteria or with the involvement or consent of the world's states, especially less developed countries. This is despite the fact that the G20 represents an important recognition of emerging economic powers such as China, India, Brazil and others. While the G20's membership is wider than the G7, it is still a selective form of cooperation which excludes many states and sits outside the UN system. Second, the informal nature of the G20's processes and outcomes mean that questions of transparency and accountability loom large. This is because it is not clear what power and authority the G20 has or how it can be held accountable for its policy debates and outcomes. It is also unclear how the G20 can develop accountability to its member states and publics let alone states outside its membership. While measures such as the outreach processes are a recent attempt to create greater transparency of the G20 process, there remains questions as to whether this development will promote a broader sense of responsibility that enables marginalized voices outside the G20 to be considered.

Third, there are questions about the appropriate scope of the G20. While the G20 was created with a focus on economic and financial issues, a broader range of social issues including climate change, corruption and health issues have been addressed by the G20 and its predecessors. This is partly because the G20's informal mandate has enabled leaders to introduce new concerns or key concerns that have not been addressed in other forums. Over time, there have been policy issues which have become reoccurring topics for the G20 precisely because of its informality. The key question facing the G20 is what the focus of the G20 should be. Should it focus on the basics of global financial regulation? Or, should it accept that it is the right forum to deal with any urgent global issues where no progress is being made and attempt to provide high level engagement with the issue in the hope that progress 
can be made? (see Carin and Shorr 2013). Fourth, there are ongoing questions about the impact and significance of the G20 process. While it is possible to see the $\mathrm{G} 20$ as an important site for the hegemony of dominant states and interests (Beeson and Bell 2009; Chodor 2017), there is also the contrasting contention that, while the G20 exists, its policy impact is inconsequential or minor (Kirchner 2016). There is also the related question of whether the G20 is limited to being a reactionary 'crisis committee' or whether it can be a 'steering committee' that is able to coordinate policy and therefore have the capacity to prevent global problems (Cooper 2010). Also relevant to this question is how important and influential the various levels of G20 summitry are. While there is the argument that the outreach groups are essentially window dressing, another claim could be that the real work of the G20 occurs in the preparations for the summit and the dominant ideas which are circulated by the policy experts and Sherpas, not only by the world leaders themselves. Important here, is the issue of how we can perceive the signs and indicators of G20 power and any resulting influence over national and global governance that such power precipitates.

Lastly, as a result of these issues, there is the question about the possible future of the G20. The future of the G20 is uncertain because of its informal and selective nature. Furthermore, it faces a range of difficult global issues where collaboration is difficult to muster. The existence of the G20 points to the need for an informal central coordinating agency for the various elements of global governance which is flexible, adaptive and includes the powerful states. While this may be partly due to the slowness and ossification of large-scale multilateral IOs, it is clear that global policy making is growing in complexity due to the problems, and the solutions, that have developed since the Second World War. This is further complicated by changes in global geopolitics and the rise of non-Western political interests and ideas, not to mention to the emerging profile of non-state transnational actors. It is also important to note that the issues that are debated in the G20 are especially stubborn and intractable and have not been effectively addressed in other forms of global governance. In this light, it is important to always consider a wide range of possibilities as to how the G20 could further adapt to this global context or be reformed to be more legitimate and effective. This requires reflecting upon the history of global governance and the broader consideration of the normative possibilities for practical action. This also means that it is valuable to consider a wider range of political traditions and assumptions going forward, even if they are complicated, inconvenient or currently unrealistic. 


\section{CONTRIBUTION OF THE VOLUME}

IR theory is able to make contributions to these questions both in terms of better understanding how the G20 operates and what future directions it could take to better adapt to contemporary and future global politics. Indeed, at a fundamental level, IR theory reveals that there are a range of different responses to these questions, which in turn stem from different assumptions about how global politics works. This volume contains chapters which are drawn from key theories of IR. The first two chapters look at liberalism (Alan Alexandroff) and realism (Steven Slaughter) respectively to examine the arguments of the first theories of the discipline of IR, which have contrasting arguments regarding the capacity of the G20 to provide robust international cooperation. The next four chapters set out the theories of rational choice (Felicity Vabulas), the English School (Tristen Naylor), constructivism (Jonathan Luckhurst) and historical institutionalism (Lora Anne Viola). These approaches set out different accounts of the drivers which influence the existence and operation of the G20. The last three chapters relate the more critical accounts of IR theory in the form of a neo-Gramscian perspective (Tom Chodor), feminism (Susan Harris Rimmer and Caitlin Byrne) and green theory (Kyla Tienhaara and Christian Downie). The volume also finishes with a conclusion which considers the future of efforts to study and understand the G20. These different theoretical accounts all make practical claims about the operation of the G20. However, these theoretical chapters each possess a different balance between being perspectives of academic analysis which seek to understand the operation of the G20 and being programs of political action which make claims about how the G20 ought to operate or issues it ought to prioritize in future.

The application of these kinds of IR theory to the G20 is important for three key reasons. First, there is a need to engage the key question of whether the G20 can be an effective form of global governance that provides strategic direction for global financial, economic and social issues. However, there are a range of different perspectives on the question of effectiveness. As such, the question of effectiveness for whom becomes particularly pertinent. It is also important to offer different responses to the ' $G$ zero' hypothesis where low expectations of global cooperation are assumed to be reality (Bremmer 2012). This means confronting the idea that global governance is inherently in 'gridlock' (Held et al 2013) by indicating how the informal and non-legal form of the G20's global summitry may be an effective alternative to reforming the UN, or the Bretton Woods system, or for the need for 
establishing new forms of multilateral treaties. Second, there is the question as to whether the G20 is a legitimate response to changing geopolitics. Again, there are various assumptions as to whether the legitimacy of the G20 matters, whether legitimacy is related to effectiveness or not, and whose support ultimately matters. This requires considering what sort of power and influence the G20 has and relating this power to changes in world politics. How can we understand the importance of legitimacy to the G20, given the changing geopolitics evident in the rising power of China, and the increasing prominence of non-state actors and transnational civil society? Third, how important is the effectiveness of the G20 with respect to other political priorities such as accountability and justice? Such a question is not often explicitly considered by policy makers but it nevertheless may be essential for the future effectiveness and legitimacy of the G20. While some traditions of IR thought may give little weight to such questions, consideration given to the normative possibilities of the G20 is potentially significant.

Answers to these political questions are not straightforward and need to go beyond the usual debates as to what is realistic with respect to global summitry. IR theory does not offer omnipotent answers to these questions. Indeed, the discipline itself needs to further adapt to a changing world in terms of the growing influence of non-Western ideas, rising forms of public concern regarding contemporary globalization and the prominence of transnational dynamics. In this context the role of IR theory with respect to informal global governance needs further examination. Nevertheless, the importance of improving global governance is hard to overstate and the role of the G20 in global governance appears prominent and potentially important. Consequently, the assumptions we make in considering these issues need to be engaged with and critically reflected upon. Engaging with a broad range of ideas drawn from the traditions of IR theory is a good place to start to reconsider the future of the G20 and global governance.

\section{REFERENCES}

Abbott, K., P. Genschel, D. Snidal, and B. Zangl (2015), 'Orchestration: Global Governance through Intermediaries', in K. Abbott, P. Genschel, D. Snidal, and B. Zangl (eds.), International Organizations as Orchestrators, Cambridge: Cambridge University Press.

Alexandroff, A. and D. Brean (2015), 'Global Summitry: Its Meaning and Scope Part One', Global Summitry, 1(1), 1-26.

Avant, D.D., M. Finnemore, and S.K. Sell (2010), Who Governs the Globe? New York: Cambridge University Press. 
Baker, A. (2009), 'Deliberative Equality and the Transgovernmental Politics of the Global Financial Architecture', Global Governance, 15(2), 195-218.

Barnett, M. and R. Duvall (2005), 'Power in Global Governance', in M. Barnett and R. Duvall (eds.), Power in Global Governance, Cambridge: Cambridge University Press.

Beeson, M. and S. Bell (2009), 'The G20 and International Economic Governance: Hegemony, Collectivism or Both?', Global Governance, 15(1), 67-86.

Bremmer, I. (2012), Every Nation for Itself: Winners and Losers in a G-Zero World, New York: Portfolio.

Carin, B. and D. Shorr (2013), The G20 as a Lever for Progress, Muscatine: Policy Analysis Brief, The Stanley Foundation.

Carr, E.H. (2016 [1941]), The Twenty Years' Crisis: 1919-1939, London: Springer.

Chodor, T. (2017), 'The G20 since the Global Financial Crisis: Neither Hegemony nor Collectivism', Global Governance, 23(2), 205-23.

Commission on Global Governance (1995), Our Global Neighbourhood, Oxford: Oxford University Press.

Cooper, A.F. (2010), 'The G20 as an Improvised Crisis Committee and/or a Contested "Steering Committee" for the World', International Affairs, 86(3), 741-57.

Cooper, A.F. (2012), The Group of Twenty: Input and Output Legitimacy, Reforms, and Agenda, Tokyo: Working Paper 372, Asian Development Bank Institute.

Cooper, A. and R. Thakur (2013), The Group of Twenty (G20), New York: Routledge.

Drezner, D. (2014), The System Worked: How the World Stopped Another Great Depression, Oxford: Oxford University Press.

Eccleston, R., A. Kellow, and P. Carroll. (2013), 'G20 Endorsement in Post Crisis Global Governance: More than a Toothless Talking Shop?', The British Journal of Politics and International Relations, 17(2), 298-317.

Feinberg, R. (2013), 'Institutionalized Summitry', in A.F. Cooper, J. Heine, and R. Thakur (eds.), The Oxford Handbook of Modern Diplomacy, Oxford: Oxford University Press.

Hale, T. and D. Held (2011), Handbook of Transnational Governance Innovation, Cambridge: Polity Press.

Held, D., K. Young, and T. Hale (2013), Gridlock: Why Global Cooperation is Failing When We Need It Most, Cambridge: Polity.

Keohane, R. (1996), 'Realism, Neo-Realism and the Study of World Politics', in R. Keohane (ed.), Neorealism and Its Critics, New York: Columbia University Press.

Kharas, H. and D. Lombardi (2012), 'The Group of Twenty: Origins, Prospects and Challenges for Global Governance', Washington, DC: The Brookings Institution, Global Economy and Development.

Kirchner, S. (2016), 'The G20 and Global Governance', Cato Journal, 36(3), 485-506.

Kirton, J. (2013), G20 Governance for a Globalized World, Aldershot: Ashgate Publishing. 
Koch, M. (2016), 'Connecting G20 Summitry with Citizenry', G20 Research Group, 16 May.

Luckhurst, J. (2016), 'The G20's Growing Political and Economic Challenges', Global Summitry, 2(2), 161-79.

Mitzen, J. (2013), Power in Concert: The Nineteenth Century Origins of Global Governance, Chicago: University of Chicago Press.

Reus-Smit, C. and D. Snidal (2010), 'Between Utopia and Reality: The Practical Discourses of International Relations', in C. Reus-Smit and D. Snidal (eds.), The Oxford Handbook of International Relations, Oxford: Oxford University Press.

Slaughter, S. (2015), 'Building G20 Outreach: The Role of Transnational Policy Networks in Sustaining Effective and Legitimate Summitry', Global Summitry, 1(2), 171-86.

Smith, S. (2004), 'Singing Our World into Existence: International Relations Theory and September 11', International Studies Quarterly, 48(3), 499-515.

Vabulas, F. and D. Snidal (2013), 'Organization without Delegation: Informal Intergovernmental Organizations (IIGOs)', Review of International Organizations, 8(2), 193-220.

Wade, R. (2011), 'Emerging World Order? From Multipolarity to Multilateralism in the G20, the World Bank, and the IMF', Politics and Society, 39(3), 347-77.

Waltz, K. (1979), Theory of International Politics, Reading, MA: AddisonWesley.

Wight, M. (1966), 'Why Is There No International Theory?', in H. Butterfield and M. Wight (eds.), Diplomatic Investigations: Essays in the Theory of International Politics, London: Allen and Unwin. 